\title{
A literature review on individual factors affecting the business performance of women entrepreneurs in Sri Lanka
}

\author{
D. C. H. De Silva ${ }^{1}$ \& L. Wijewardene ${ }^{2}$ \\ ${ }^{1}$ Department of Entrepreneurship, Faculty of Management Studies and Commerce, \\ University of Sri Jayewardenepura, Sri Lanka \\ ${ }^{2}$ Business Communication Unit, Faculty of Management Studies and Commerce, \\ University of Sri Jayewardenepura, Sri Lanka
}

\begin{abstract}
Entrepreneurship is considered as a critical factor for the economy of any country, as well as the engine of economic growth, since it leads to generate income locally or internationally and ultimately facilitates economic progression. It emphasizes not only the generating of income but also increasing living standards of the people and accelerating production, etc. Women Entrepreneurship has attracted the attention of the scholars, as being one of the crucial factors of economic growth of a country. Sri Lanka needs to pay high consideration on women entrepreneurship since more than half of thetotal population of the country consists of women. Women entrepreneurship generates new job opportunities to the society and influences the providing of innovative management solutions to the business world. Even though women entrepreneurship can be identified as having a large number of benefits and advantages, still there are barriers and challenges for women when they stand as entrepreneurs. The study is carried out as a literature review with the main objective of identifying the individual factors affecting the business performance of women entrepreneurs in Sri Lanka. According to the study, a large variety of individual factors such as human capital, social learning, financial capability, network affiliation, motivation goals etc. can be identified. The results of the analysis will be useful in implementing practical implications specially to women entrepreneurs, Small and Medium Enterprises, government institutions and regulatory bodies etc. by empowering women to engage with more entrepreneurial activities while overcoming their barriers successfully. With this insight, Sri Lanka is paving a new pathway towards a new growth era through the boosting of women entrepreneurship by ensuring to strengthen therole that women play in the economy.
\end{abstract}

Keywords - Entrepreneurship, human capital, social learning, financial capability, network affiliation, motivation goals 


\section{Introduction}

Sri Lanka has failed its efforts of ensuring the economic progress when compares to many developing countries in Asia even though the country is enriched with vast variety of natural resources and fruitful human resources. Small and Medium Enterprises (SMEs) and Entrepreneurship can be considered as one of the most decisive factors of economic development of a particular country since it has the ability of generating income locally and internationally, generating the employment opportunities, higher consumer spending and more production while all these benefits lead the whole country to increase the living standards of the people. Therefore, the vital role of SMEs and Entrepreneurship which is playing at the economy is identified as the engine and a critical driving force of the economy.

Women Entrepreneurship is also recognized as an important source and one of the most crucial factors of economic growth of a developing country like Sri Lanka since it is having more than half portion of women population out of total population of the country. Women entrepreneurship generates new job opportunities to the society, it also influences to provide innovative management solutions to the business world. Even though variety of advantages can be identified, still there are number of barriers when a woman is entering to the business world such as gender discrimination, matrimonial problems, cultural barriers, lack of finance etc (Hisrich, 1981).

Women entrepreneurs have kept their name as a significant driving force in every economy since they play a dual role in same time as house wives and entrepreneurs. In a developing country like Sri Lanka, women entrepreneur's role is highly evaluated since they provide a considerable active participation to the economic development of the country. When focusing on entrepreneur's role and the Sri Lankan economy, past history shows that there is no considerable contribution of women entrepreneurship to the development of the economic level of the country. But in recent past the situation has changed and there is a considerable active participation of women entrepreneurs to the Sri Lankan economy even though the numbers of female entrepreneurs are still relatively low. At the same time there can be identified an increase of number of women entrepreneurs and their business performance and large number of driving factors have influenced that (Hemalatha, 2005).

Women entrepreneurship is also a very interesting topic since it was discussed 
by large number of researchers in all over the world during past years. The main reason behind that is, female entrepreneurs are performing very well rather than male entrepreneurs in some situations. Because of this situation, most of the researchers in western countries like Canada, United Kingdom, and United States of America have focused on examining what are the success factors and what are the failure factors which impact on the business performance of women entrepreneurs (Hisrich, 1987).

When it comes to the Sri Lankan context, the situation seems to be similar to the international context since most of the female entrepreneurs are performing well than most of the male entrepreneurs. Most of the successful women entrepreneurs have stepped forward in to the international market breaking the local boundaries.

By focusing on the available literature regarding the chosen research scope in Sri Lankan context, it can be identified that limited number of researches have conducted based on women entrepreneurship even though there are many researches which covers the male entrepreneurship part (Ranasinghe, 1996). Hence this study aims to conduct a systematic literature survey with the main purpose fulfilling the knowledge gap with regards to identifying the individual factors affecting the business performance of women entrepreneurs in SriLanka.

The contribution and the implications of the study can be identified in both theoretical and practical perspectives. The theoretical contribution of the study will be as follows. Since there is a huge gap in this research area when comparing to the world context with the Sri Lankan context, this study will be very important to future researches as a preliminary study and provide guidance for the future researches. All the scholars who are interested in the field of women entrepreneurship, individual factors affecting the business performance of women entrepreneurs, will be benefitted from the findings of this research study. Hence this study will be a future insight for those people who are interested in the field of women entrepreneurship.

Furthermore practical contribution of the study can be discussed through support, make or re-correct the available policies, procedures and strategies in the field of women entrepreneurship. This research will be important for the decision makers and policy makers who are engaged in government sector as well as non-government sector in order to develop the field of women entrepreneurship by providing more financial facilities, providing training and development facilities for women 
entrepreneurs and developing women affairs like networking etc.

\section{Literature review}

This section dedicated to analyze the literature review related to the research area including sub sections such as entrepreneurship and women entrepreneurship, human capital, social learning, financial capability, motivation and goals, network affiliation, industrial factors and business performance.

\subsection{Entrepreneurship}

The field of entrepreneurship is massive or vast area to discuss. Because of this reason nobody can give an exact definition emphasizing what is entrepreneurship. With the challenges and issues occurred when defining the concept of entrepreneurship, large variety of discussions and arguments can be identified by referring the available literature on this field. Most of the definitions regarding entrepreneurship are based on characteristics of entrepreneur, parts of entrepreneurial process and results of entrepreneurial process (Kobia, 2010).

Entrepreneurship can be considered as one of the most powerful driving forces in an economy. Due to that reason the concept relating to Entrepreneurship has been discussed since recent past decades and many more scholarly articles and their researchers have presented their own views on this regard. The very first discussion regarding the concept of Entrepreneurship was took place in the year of 1732 by Richard Cantillon (Kavuli, 2014).

Furthermore according to Kearney, Entrepreneurship can be defined as translating process of vision in to a successful business enterprise by an individual person. Simply it is a "creation of new organizations by exploiting new profitable business opportunities" (Kearney, 2007). According to Minniti (2008), Entrepreneurship has defined as willingness and preference to carry out a new venture by taking a financial risk.

By considering all these available definitions, Entrepreneurship can be identified as a mindset of an individual which formulate profitable business ideas and opportunities in to business organizations while allocating resources and bearing a moderate risk.

Since every individual can define the concept of Entrepreneurship according to their own perspectives, the field of Entrepreneurship has no clear boundaries neither any clear conceptual frame works also (Busenitz, 2003; Ireland, 2007). 
Entrepreneur can be considered as the action form of the concept of the Entrepreneurship. This part is also defined by many researchers previously. Schumpeter has defined an entrepreneur as, "a person who innovates, who allocates and manages the factors of production and bears risk, as an individual who is driven by a high need for achievement, who prefers to work on moderately difficult tasks, exerts his/her own efforts to obtain results and takes personal responsibility for the results, and one who needs more feedback on performance" (Schumpeter, 1934). According toWoolf (1980), entrepreneur is a person who can organize and manage the business organization or the enterprise and who assumes the embedded risk component with that.

Simply entrepreneur is as an individual or person who starts something or undertaking something. Summary of definitions on entrepreneurship can be presented as follows other than the discussions above had.

\subsection{Human capital}

According to Hisrich (1982), human capital can be defined as, "supportive skills or anilities and capabilities of an individual developed through education and experience". This is based on six dimensions, educational level, educational area, previous occupation, previous entrepreneurial experience, experience in the industry, business skills.

Level of education as well as previous experiences as an entrepreneur can be considered as two factors which affected to start a new business as well as the performance of the business of that entrepreneur. Formal education of the entrepreneur can hugely make impacts on the performance of the business (Cooper, 1989; Brush, 1993; Brush, 1991; Dolinsky, 1993). Box (1993) stated that higher level of education has caused to increase the performance of the business at the research study which as carried out at Oklahoma. By considering the summary of above mentioned studies, they have revealed that if any women entrepreneur is having less education she might be facing problems, issues and limitations such as financial problems, human capital constraints etc.

\subsection{Social learning}

Social learning theory was introduced by Bandura in 1977 and the concept mainly relies with the role of entrepreneurial socialization since it explains the behavioral pattern of the entrepreneurs and lead to career development. This can be occurred through the observation the behavior of 
other people specially role models (Bandura, 1977).

According to Hisrich (1982), social learning can be defined as, socialization process of each individual's which is also engaged with family setting transmits social norms, language, educational aspirations and shapes career preferences through observational learning and modeling. This concept is based on four dimensions namely, parent entrepreneur, husband entrepreneur; someone was role model, economic status at childhood (Hisrich, 1982).

Performance of a particular person is also very high if the parent performing a role as entrepreneur. Specially most of the times the father's role as a parent considered here (Scherer, 1989; Belcourt, 1991). From the early stages of the childhood of a entrepreneur, they have followed their parent's behaviors. This has caused to increase the performance of the business. Furthermore women entrepreneurs are taking the expectancy for an entrepreneurial career, educational knowledge, training aspirations, task self-efficacy from their parents. There is an opposite opinion presented by Hisrich et al.(1997) and it says that family socialization is not impacted to the business performance specially in cases like father is self-employed and engaged with a business activity.

Scherer (1989) also revealed that entrepreneurs, who are having role models for their career, perform well in their activities rather than the people who are not having role models. Lerner (1992) shows that entrepreneurs believe in their parents as role models specially if the father is an entrepreneur. It also concludes that there is a clear relationship between having role model for the career and the performance of that person not only the business performance but also in other activities too.

Economic status at the childhood of entrepreneur has made an impact on the business performance of the entrepreneurs and it is also including in the conceptual framework which is developed by Hisrich and Brush (1982); Hisrich and Brush (1985). It is because women, who had the economic issues at their childhood, have started their own businesses when they are getting mature.

\subsection{Financial capability}

Venture capital can be considered as one of the major important factors of the financial capability of an entrepreneur. If the particular entrepreneur can find out his or her venture capital, this will favorably impact to the business 
performance of the particular entrepreneur(Bruno, 1982).Brophy (1989) stated that availability and capability to find sufficient start-up capital is one of the most influencing environment factor which directly affecting the business performance of women entrepreneurs. Empirical evidences are shown in an American study which was conducted by using 346 of entrepreneurs in Washington. And it was found that there is a significant relationship between capability to find the venture capital and the business performance without considering the gender differences as between female entrepreneurs and male entrepreneurs (Miskin \& Rose, 1990).

And also if there are enough loan facilities, financial support services for the entrepreneurs that will also be favorably impact to the business performance (Bruno, 1982). When there are enough loan facilities, entrepreneurs are motivated to get loans and fulfill their financial requirements since they are getting enough alternatives to select one effective loan scheme among more financial options.

Usually women get tired and discouraged when seeking funds from financial institutions because of the thoughts that their loan applications will be rejected by those financial institutions. So ultimately women are become to discouraged borrowers and it will cause to reduce the rate of start-up businesses of women (Kon, 2003).

According toSkarlatos (2004), there can be identified gender related disadvantages and limitations when women entrepreneurs getting the benefits from the access in micro credit facilities. Women are more likely to have financial barriers than men when they start-up their own business. The gender is considered as the most important thing by financial institutions when women applied for borrowings from them.

\subsection{Motivations and goals}

Motivations and goals is a factor which deals with individuals' intensity, persistence of effort and the direction of achieving a particular goal or an objective. Motivations towards the goals can be measured by using the indicators such as achievement motives, independence motives, economic necessity motives and personal goals (Hisrich, 1982; Lerner et al. 1997). Basically psychological motivations are used when considering the motivations and it also includes that independence of working, locus of control, achievements in career etc. (Brockhaus \& Horwits, 1986). 
There can be identified few studies regarding how motivations and goals affecting the business performance of women entrepreneurs. According to the study conducted by Hisrich and Brush(1987) in United States of America, there is a close relationship between motivations, goals with the performance of women owned businesses specially. Furthermore it emphasized that the owners are getting motivated according to the opportunities that they get and it impacts on the survival of the business.

The findings of the research which is conducted by Lerner et al.(1997) in Israel context indicates that, there is a significant relationship between motivations goals and the business performances specially when it comes to the business organizations that women entrepreneurs are owned. According to their research motivations goals are deals with various aspects of the performance of the business. They have used indicators such as achievement, economic necessity and independence in order to measure the motivations goals where economic necessity is correlate with profitability, achievement strongly correlate with income level of the business and independence correlate with revenue. different from male entrepreneurs in the perspective of motivations and goals. Kaleberg and Leicht (1991) suggest that there is a significant difference between female and male entrepreneurs when considering the motivations like achievements and independence. Miskin and Rose (1990) also stated that the condition of the female entrepreneurs is in a low level when compares to the male entrepreneurs in the perspective of self-confidence.

\subsection{Network affiliation}

The concept of network affiliation deals with building up social networks and relationships by an individual person. Furthermore this can be measured by using the measurements such as number of networks, use of advisors, memberships in associations and mentors etc. (Hisrich \& Brush, 1985). According to Aldrich and Zimmer (1986), entrepreneurship is affected by having proper networks in positive manner or the negative manner by linking the entrepreneurs, resources and opportunities. Furthermore it says that having networks is highly influenced to the business performance. When comparing male entrepreneurs, women are having different kind of network systems and the ability to build the networks is limited in that case.

When it comes to the gender differences, female entrepreneurs are significantly 
Dharmaratne (2012) emphasized the situation in Sri Lanka regarding the factor of network affiliation. According to that study, the researcher explained that most of the Sri Lankan women are reluctant to join with social networks because of lack of time.

\subsection{Industrial factors}

According to Hisrich and Brush (1985), the industrial factors including different structure of opportunities, location, market situation, socio political environment, resource availability can be effected business performance of women entrepreneurs.

The performance of a business is mainly measured by using economic measures such as profitability revenue and number of employees etc. Because of this reason economic environmental factors can be affected by the business performance significantly. Lerner et al.(1991) found that there is a significance relationship between the industrial and environmental factors and the business performance of women entrepreneurs in Israel context.

Further Gibb (1988) proved that industrial factors such as location of the business, sectoral activities, and sociopolitical factors like availability of government assistance can directly affect to the business performance of women entrepreneurs. At the same time Gibb (1988) revealed that economical factors can be influenced critically on business performance. It may depend on the structure of the market, regional opportunities, investment climate, labor availability etc. Similarly resource availability including labor force with adequate technical skills, availability of business support services, favorable entrepreneurial sub culture can be hugely affected to the business performance of women entrepreneurs (Bruno \& Tybjee, 1982).

The same findings were proved by Dharmaratne (2012) at the Sri Lankan context as industrial factors are favorably affected to the business performance of Sri Lankan women entrepreneurs.

\subsection{Business performance}

The performance of a business is a very complex and it is very difficult to operationalize since there can be identified multidimensional phenomenon in order to measure the business performance (Dess \& Robinson, 1984). Business performance can be measured by using financial perspective, non financial perspective or using both. Most of the scholars are using both methods to measure the business performance. 
Dharmaratne (2012) defined the business performance as the way that organization is measuring their effectiveness on the fields such as how they are doing financially, the way that organization is facing to the competition, market growth of the business and achievements and improvements of the business.

According to Hisrich(1982), it can be used five dimensions namely, revenue, profits, ability to face competition, business expansion, business achievements, in order to measure the performance of a particular business.

\section{Methodology}

The study is carried out as a systematic literature review with the main objective of identifying the individual factors affecting the business performance of women entrepreneurs in Sri Lanka. According to Dahlander and Gann (2010), it is proven and accepted by the scholars and scientists that online data bases and information related to particular research area are resourceful and those will provide a comprehensive examination within the scholarly and subjects' environment. The researcher focused on data bases such as Google Scholar, Research Gate, Emarald Insight etc. for the analysis. Even though these data bases are consisted with high quality publications, only very few sources could be found related to the research area specially reference to the Sri Lankan context while most of them based on western countries.

The study was based on more than 50 applicable research articles directly related to the research area published at different kind of data bases. A careful investigation was conducted to ensure the fluency of related theories and concepts related to the women entrepreneurship while maintaining the consistency of the literature.

According to the core of the literature review of the study, following conceptual model was developed as follows in Figure 1 in order to address the research question of the study.

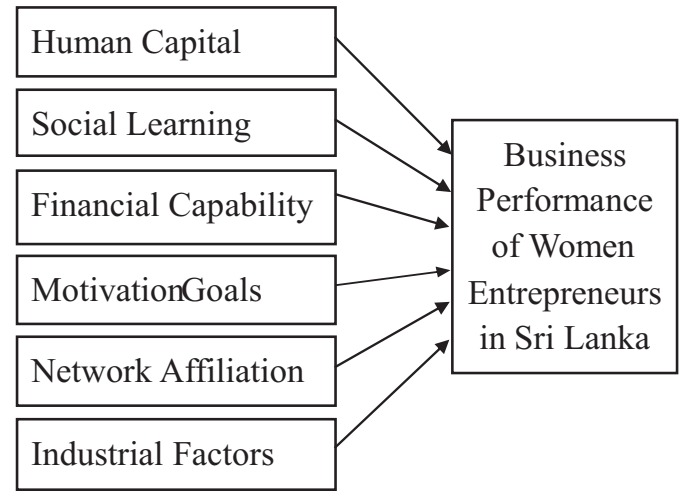

Figure 1: Conceptual model

\section{Results and Discussion}

Sri Lanka is a country which considered as a developing country yet and heads toward an economic development and sustainable growth. As mentioned in the 
previous chapters, majority of the total population of the country is consisted with female population. Hence involvement of women population with entrepreneurship will provide greater solutions for the economic issues such as disparity in income distribution, high rate of unemployment, utilizing the natural resources etc.

Almost all the studies which were taken to the attention for this research study revealed that the identified factors such as human capital, social learning, financial capability, network affiliation, motivation and goals, industrial factors are having significant impact on the business performance of the women entrepreneurs in Sri Lanka (Dharmaratne, 2012). Therefore, the study also paid attention on developing the recommendations according to the findings of the study for the betterment of the study area.

According to Muller (2006) it suggests that to establish industrial or business centers specially for women entrepreneurs with the main aim of providing relevant entrepreneurial experiences, adequate business skills, specially the industrial experience as well as financial facilities etc. Women entrepreneurs can get the expertise advices, share knowledge and their experiences; get training and development facilities, networking and communication via these kinds of industrial and business centers.

Another very important recommendation is improving the accessibility to finance of the women entrepreneurs. This suggestion can be implemented by using the strategies such as developing mandated loan portfolios specially for female entrepreneurs, establishing gender sensitive bank branches etc. Accordingly gender sensitive training in banking practices can be introduced to the bank managers and loan officers in order to eliminate the gender discriminations when women entrepreneurs are getting the access to finance (Women's Chamber of Industry and Commerce, 2015).

Furthermore the awareness regarding the loan facilities and micro credit facilities should be improved since the study shows that there is a lack of knowledge and awareness regarding those facilities among most of women entrepreneurs. In order to increase the awareness government can directly involve with the financial institutions and organize sessions, programs, and workshops in order to improve the financial literacy of the women entrepreneurs (Rathiranee \& Semasinghe, 2012). 
Apart from the financial facilities, women entrepreneurs can be benefitted from the mentoring and business development support services. According to the literature available, most of the women owned business firms are getting low profits and having lower performances due to the lack of mentorship, advisory and business development support services. Government and other relevant authorities must pay more attention on this regard also (Women's Chamber of Industry and Commerce, 2015).

Another recommendation is to make easy the regulatory burden which is mostly impact to the women entrepreneurs. It is really very important because having easy regulatory framework is always encouraging women to involve with entrepreneurship and business activities more and more (Women's Chamber of Industry and Commerce, 2015).

\section{Conclusion}

Entrepreneurship is one of the fundamental requirements for an economic progress specially for a developing country like Sri Lanka. Furthermore it can be used as a competent tool when competing with developed countries since it facilitates to exploit new opportunities, engage with innovations and ultimately wealth creating through them in order to uplift the living standards of the people of the country. Furthermore entrepreneurship is an effective timely solution for most of the economic issues that the country is currently facing such as income disparity, high unemployment rate etc. Because of these reasons empowering entrepreneurs has become a timely requirement. Specially Sri Lanka is a country which is having majority of women out of total population, this can be very critical factor. This is why encouraging women towards entrepreneurship is very essential in starting new ventures as well as increasing their business performance. With accordance to that, the researcher has conducted this study with main objective of identifying individual factors affecting the business performance of women entrepreneurs with special reference to Colombo District, Sri Lanka.

According to the findings of the study large number of factors could identified as the individual factors which affecting the business performance of women entrepreneurs in Sri Lanka such as human capital, social learning, financial capability, network affiliation, motivation and goals, industrial factors etc. most of the studies have emphasized that there are significant positive relationships and those identified factors can significantly impacted to the 
business performances of women entrepreneurs in Sri Lanka specially factors like human capital, social learning and financial capability.

\section{References}

Aldrich, H.(1989), Networking among women rntrepreneurs as cited in Hugan, O., Rivehun, C., Sexton,D., 'Women owned businesses', New York, 103-132.

Aldrich, H., \& Zimmer, C.(1986), Entreprenurship through social networks as cited in Sexton,D., Simlor, R. W., The art and science of entrepreneurship, Campbridge, MA, Ballinger Publishing Co., 3-23

Bandura, A. (1977), Social Learning Theory, Englewood Cliffs, PrenticeHall, N.J.

Belcourt, M. B.G.,Burke, R.J., \& LeeGosselin, H. (1991), The glass box: Women Business Owners in Canada: Background paper, Ottawa, Ontario: Canadian Advisory Council on the Status of Women.

Box, T. W.,White, M.A., \& Barr, S.H. (1993), A contingency model of new manufacturing firm performance, Entrepreneurship Theory and Practice, 2(18), 31-45.

Brockhaus, R.H., \& Horwitz, P.S. (1986), The psychology of the entrepreneur, as cited in Sexton, D.L., \&Smilor, R.W., The Art and Science of Entrepreneur ship, Cambridge, MA: Ballinger Publishing Co.

Brophy, D. J. (1989), Financing women owned entrepreneurial firms as cited in Hugan, O., Rivehun, C., \& Sexton, D., Women owned businesses, New York, 55-75.

Bruno, A.V., \& Tybjee, T.T. (1982), The environmentfor entrepreneurship.

Brush, C.G., \& Hisrich, R. D.(1991), Antecedent influences on womenowned businesses, Journal of Management Psychology, 2(6), 9-16.

Busenitz, L. W. (2003), Entrepreneurship Research in Emergence: Past Trends and Future Directions, Journal of Management, 3(29), 285-308.

Chaganti, R., \& Parasuraman, S. (1994), Venture performance, gender, goals, business strategies and management practices, Working Paper, Rider College.

Cooper, A. C. (1989), Strategic Management: New Ventures and Small Businesses Long Range Planning, 5(14), 39-55.

Cooper, A.C.,\& Gascon, E.J.G. (1992), Entrepreneurs, processes of founding, and new-firm performance.

Dahlander, L., \& Gann, D.(2010), How open is innovation? Research Policy, 39(6), 699-709.

Dharmaratne, K. L. B. G. (2012), Impact of Individual Factors on the Business Performance of Women Entrepreneurs in Sri Lanka, Sabaragamuwa University Journal, (11), 139-165

Dess, G.G., \& Robinson, R. B. (1984), Measuring Organizational Performance in the Absence of Objective Measures, The Case of The Privately Held Firm and Conglomerate Business Units, 
Strategic management Journa, 265273.

Dolinsky, A. L., Caputo, R. K., Pasumaty, K., \& Quanzi, H. (1993), The effects of education on business ownership: A longitudinal study of women entrepreneurship, Entrepreneurship Theory and Practice, 1(18), 43-53.

Freel, M. C.(2007), The Latent Demand for Bank Debt: Characterizing "Discouraged Borrowers". Cardiff: paper presented at the RENT conference.

Hemalatha, S.(2005), Women in local politics: A study of women's participation in the politics of Sabaragamuwa province from 1987 to 2005, an unpublished document.

Hisrich, R.D.,\& Brush, C. G. (1985), Women and minority entrepreneurs: A comparative analysis, In Frontiers of Entrepreneurial Research Cambridge, MA: Babson College, 566-586.

Hisrich, R.D.,\& Brush, C. G. (1987), Women entrepreneurs: A longitudinal study, Frontiers of entrepreneurship research, 87-199.

Hisrich, R. D., \& Brush, C. G. (1982), The woman entrepreneur as a reflection of type of business, Frontiers of Entrepreneurship Research, 54-67.

Hisrich, R. D.,\& Brush, C. G. (1982), The woman entrepreneur as a reflection of type of business, In Frontiers of Entrepreneurship Research 1982. Cambridge, MA: Babson College, 5467.

Hughes, K.(2012), Global women's entrepreneurship research: Diverse settings, questions and approaches, Cheltenham: Edward Elgar.

Ireland, R. D. (2007), A Cross-Disciplinary Exploration of Entrepreneurship Research, Journal of Management, 6 (33), 891-927.

Johnson, S., \& Storey, D. (1994), Male and Female Entrepreneurs and their businesses: a comparative study as cited in Allen. S., \& Truman, C., Women in business: Perspectives on Women entrepreneurs, London, Routledge Press, 70-85.

Kalleberg, A.L., \&Leicht, K.T. (1991),Gender and organizational performance: Determinants of small business survival and success, Academy of Management Journal, 34(1), 136-161.

Kavuli, K. L. (2014), Factors influencing women participation in entrepreneurial activities in Kasikeu Division Makueni Country, University of Nairobi.

Kearney, C. H. (2007), A conceptual model of public sector corporate entrepreneurship, International Entrepreneurship and Management Journal, 4(3), 295-313.

Kobia, M.,\& Sikalieh, D.(2010), Towards a search for the meaning of entrepreneurship, Journal of European Industrial Training, 34(2), 110-127.

Kon, Y. (2003), A Theory of Discouraged Borrowers, Small Business Economics, 37-49.

Lerner, M. (1992), Stratification sources of entrepreneurship recruitment, In Frontiers of Entrepreneurship 
Research. Cambridge, MA: Babson College, 75-88.

Lerner, M., Brush,C. G., \& Hisrich R. D. (1997), Israeli Women Entrepreneurs: An examination of factors affecting performance, Journal of Business Venturing.

Minniti, M. (2008), Recent developments in the economics of entrepreneurship, Journal of Business Venturing , 603612.

Miskin, V., \& Rose, J. (1990), Women entrepreneurs: Factors related to success. In Frontiers of Entrepreneur ship Research, Cambridge, MA: Babson College, 27-38.

Muller, C. (2006), Factors affecting women entrepreneurs in establishing and expanding their businesses in NAD Province, International Labour Organization.

Ranasinghe, S. (1996), Entrepreneurship education and training in Sri Lanka, Sri Lanka Journal of Management, 1 (3), $262-277$.
Rathiranee, Y., \& Semasinghe, D. M., Challenges facing by women in accessing credit from microfinance institutions in Sri Lanka.

Scherer, R. A.(1989), Role model performance effects on development of entrepreneurial career preference, Entrepreneurship Theory and Practice, 53-71.

Skarlatos, K. (2004), Microfinance and Women's Economic Empowerment, Bridging the Gap, Redesigning the Future, Wisconsin Coordinating Council, Nicaragua.

Woolf, H. B. (1980), Webster's New Collegiate Dictionary, MA: G. \& C. Merriam Company, MA: G. \& C. Merriam Company, Springfield.

Women's Chamber of Industry and Commerce (2015), Fostering women's entrepreneurship in the SME sector in Sri Lanka. 